Check for updates

Cite this: RSC Adv., 2018, 8, 24068

\title{
Integrated conversion of 1-butanol to 1,3- butadiene $\uparrow$
}

\author{
Jacob S. Kruger, (D) * Tao Dong, Gregg T. Beckham (DD) and Mary J. Biddy
}

Renewed interest in production of 1,3-butadiene from non-petroleum sources has motivated research into novel production routes. In this study, we investigated an integrated process comprising 1-butanol dehydration over a $\gamma-\mathrm{Al}_{2} \mathrm{O}_{3}$ catalyst to produce a mixture of linear butenes, coupled with a downstream $\mathrm{K}$-doped $\mathrm{Cr}_{2} \mathrm{O}_{3} / \mathrm{Al}_{2} \mathrm{O}_{3}$ catalyst to convert the butenes into butadiene. Linear butene yields greater than $90 \%$ are achievable at $360{ }^{\circ} \mathrm{C}$ in the dehydration step, and single-pass 1,3-butadiene yields greater than $40 \%$ are achieved from 1-butene in a $\mathrm{N}_{2}$ atmosphere in the dehydrogenation step. In the integrated process, 1,3-butadiene yields are 10-15\%. In all cases, linear C4 selectivity is greater than 90\%, suggesting that 1,3-butadiene yields could be significantly improved in a recycle reactor. Doping the $\mathrm{Cr}_{2} \mathrm{O}_{3}$ catalyst with different metals to promote $\mathrm{H}_{2}$ consumption in a $\mathrm{CO}_{2}$ atmosphere did not have a large effect on catalyst performance compared to an undoped $\mathrm{Cr}_{2} \mathrm{O}_{3}$ catalyst, although doping with $\mathrm{K}$ in an $\mathrm{N}_{2}$-diluted atmosphere and with $\mathrm{Ni}$ in a $\mathrm{CO}_{2}$-enriched atmosphere showed slight improvement. In contrast, doping with $\mathrm{K}$ and $\mathrm{Ca}$ in a $\mathrm{CO}_{2}$-enriched atmosphere showed slightly decreased performance. Similarly, employing a $\mathrm{CO}_{2}$-enriched atmosphere in general did not improve 1,3-butadiene yield or selectivity compared to reactions performed in $\mathrm{N}_{2}$. Overall, this study suggests that an integrated dehydration/dehydrogenation process to convert 1-butanol into 1,3-butadiene could be feasible with further catalyst and process development.

Received 6th April 2018

Accepted 19th June 2018

DOI: $10.1039 / c 8 r a 02977 f$

rsc.li/rsc-advances
Several pathways to convert biomass to a renewable $\mathrm{C} 4$ stream exist commercially, incorporating syngas, methanol, and ethanol intermediates en route to 1-butanol, isobutanol, succinic acid, or butanediol. ${ }^{2,6}$ The pathways to convert these C4s into 1,3-butadiene are less technically developed, though the embodied chemistries are relatively mature. Specifically, 1butanol could be dehydrated to 1- and 2-butenes, and these butenes could be dehydrogenated to 1,3-butadiene (Scheme 1).

A single-stage integrated process would be challenging due to the different conditions required for alcohol dehydration and olefin dehydrogenation. In particular, olefin dehydrogenation is typically carried out at temperatures greater than $550{ }^{\circ} \mathrm{C}$ and weight-hourly space velocities (WHSVs) greater than $150 \mathrm{~h}^{-1}$. High temperature is required to activate the olefins on the dehydrogenation catalyst, and the high WHSV is required to minimize unfavourable side reactions that lead to $\mathrm{C} 1-\mathrm{C} 3$ cracking products and coke. Additionally, dehydrogenation catalysts $\left(\mathrm{Cr}_{2} \mathrm{O}_{3}\right.$ or $\mathrm{Fe}_{2} \mathrm{O}_{3}$ supported on $\left.\mathrm{Al}_{2} \mathrm{O}_{3}\right)$ are typically doped with $\mathrm{K}_{2} \mathrm{CO}_{3}$ or $\mathrm{K}_{2} \mathrm{O}$, which neutralize catalyst acidity that would be necessary for alcohol dehydration. Similarly, alcohols tend to react by dehydrogenation at such temperatures to produce an undesired carbonyl, rather than by dehydration to produce a desirable olefin. ${ }^{7}$ On the other hand, 1-butanol can be dehydrated to linear butenes in greater than $95 \%$ yield over a $\gamma$ $\mathrm{Al}_{2} \mathrm{O}_{3}$ catalyst at temperatures of $350-410^{\circ} \mathrm{C}$ and WHSVs of $1-10$ $\mathrm{h}^{-1} .{ }^{8}$ This difference in reaction conditions may be one reason
National Renewable Energy Laboratory, National Bioenergy Center, 15013 Denver West Parkway, Golden, CO 80401, USA. E-mail: Jacob.Kruger@nrel.gov

$\dagger$ Electronic supplementary information (ESI) available: Reactor temperature profile, control reaction product distributions, additional doped catalyst results, effect of $\mathrm{H}_{2} \mathrm{O}$-rich. See DOI: 10.1039/c8ra02977f 


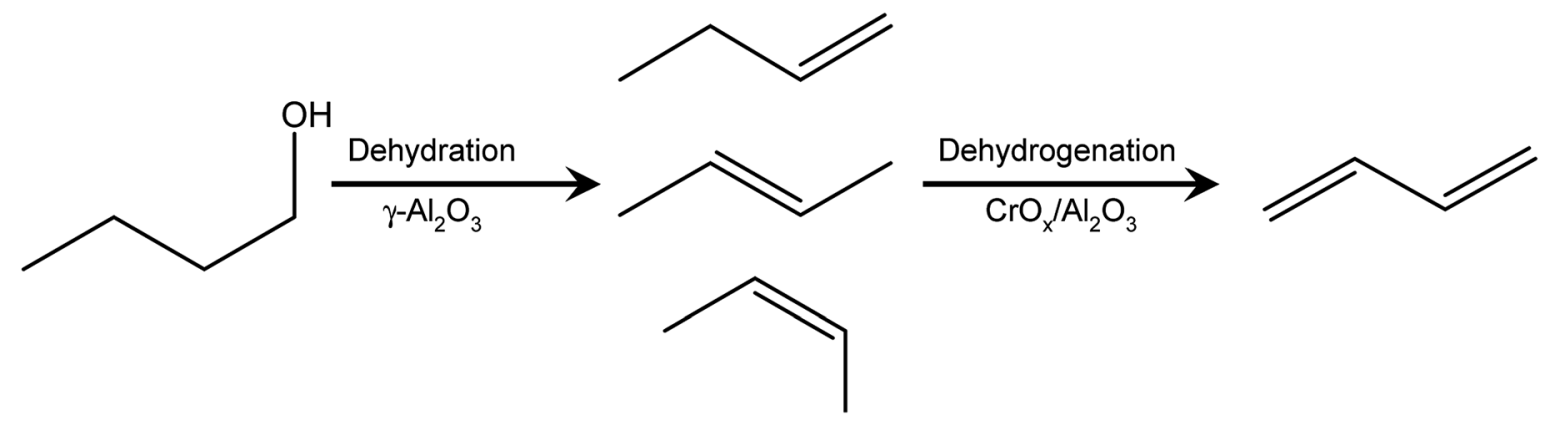

Scheme 1 Dehydration of butanol to linear butenes, and dehydrogenation of butenes to 1,3-butadiene.

that it has been suggested, ${ }^{\mathbf{1}}$ but never demonstrated, that an integrated dehydration-dehydrogenation process to convert 1butanol to 1,3-butadiene could be feasible.

We hypothesized that olefin dehydrogenation could also be operated at lower temperature by decreasing the space velocity, and that the lower temperature would also be advantageous in mitigating side reactions. While cracking equilibria still strongly favour $\mathrm{C} 1-\mathrm{C} 3$ products at temperatures as low as $450{ }^{\circ} \mathrm{C}$, the kinetics of these reactions are much slower. ${ }^{9}$ Thus, we were motivated to explore the integrated conversion of 1butanol to 1,3-butadiene in a combined dehydration-dehydrogenation reactor.

Additionally, we were interested in improving yields in the butene dehydrogenation step. Linear butenes can typically be directly dehydrogenated over $\mathrm{CrO}_{x} / \mathrm{Al}_{2} \mathrm{O}_{3}$ or $\mathrm{Fe}_{2} \mathrm{O}_{3}$-containing catalysts in single-pass yields of $40-50 \%$ or oxidatively dehydrogenated over $\mathrm{ZnFe}_{2} \mathrm{O}_{4}, \mathrm{Bi}_{2} \mathrm{MoO}_{6}$, or $\mathrm{Sn} / \mathrm{Sb}$-containing catalysts in single-pass yields of $60-70 \% 0^{1,9-12}$ The oxidative dehydrogenation shifts the dehydrogenation equilibrium toward 1,3-butadiene by converting the produced $\mathrm{H}_{2}$ to $\mathrm{H}_{2} \mathrm{O}$. The presence of $\mathrm{O}_{2}$ and $\mathrm{H}_{2} \mathrm{O}$ concomitantly mitigate coke formation on the catalyst surface.

In dehydrogenation without $\mathrm{O}_{2}$, alternative concepts for shifting the dehydrogenation equilibrium may also be feasible. In particular, (1) coke gasification or methanation, (2) $\mathrm{CO}_{2}$ methanation, and (3) reverse water-gas shift (RWGS) are three reactions that could consume produced $\mathrm{H}_{2}$.

$$
\begin{gathered}
\mathrm{C}+2 \mathrm{H}_{2} \rightarrow \mathrm{CH}_{4} \\
\mathrm{CO}_{2}+4 \mathrm{H}_{2} \rightarrow \mathrm{CH}_{4}+2 \mathrm{H}_{2} \mathrm{O} \\
\mathrm{H}_{2}+\mathrm{CO}_{2} \rightarrow \mathrm{H}_{2} \mathrm{O}+\mathrm{CO}
\end{gathered}
$$

Of these three, reaction (3) has proven promising in dehydrogenation of ethylbenzene to styrene and diethylbenzene to divinyl benzene ${ }^{13-15}$ and to some extent in butene dehydrogenation. ${ }^{16-19}$

To this end, certain catalysts are known to promote these desired reactions. In particular, coke gasification can be promoted by $\mathrm{K}, \mathrm{Ca}$, and $\mathrm{Ni} ;{ }^{20} \mathrm{Ni}, \mathrm{Fe}$, and $\mathrm{Mo}$ can hydrogenate $\mathrm{CO}_{2}$ to $\mathrm{CH}_{4} ;^{21,22}$ and RWGS can be promoted by $\mathrm{Fe}_{2} \mathrm{O}_{3}$ and $\mathrm{Cu} /$ $\mathrm{CeO}_{2} \cdot{ }^{13,23} \mathrm{~K}$ and $\mathrm{Ca}$ can also help to poison catalyst acid sites that lead to unfavourable cracking reactions, which in turn lead to coke. ${ }^{9}$

Thus, in addition to demonstrating an integrated butanolto-butadiene process, we were motivated to explore the potential of new equilibrium-shifting catalysts for butene dehydrogenation. Herein we report process development for 1-butene dehydrogenation over a series of $\mathrm{Cr}_{2} \mathrm{O}_{3} / \mathrm{Al}_{2} \mathrm{O}_{3}$ catalysts doped with $\mathrm{K}, \mathrm{Ca}, \mathrm{Ni}, \mathrm{Mo}, \mathrm{Fe}$, and $\mathrm{Cu} / \mathrm{CeO}_{2}$, and integration with 1-butanol dehydration.

\section{Experimental}

\section{Materials}

1-Butene (5.4 mol\% in $\mathrm{N}_{2}$ ) and a GC calibration standard of 1butene, cis-2-butene, trans-2-butene, 1,3-butadiene, and $n$ butane ( $1 \mathrm{~mol} \%$ each in $\mathrm{N}_{2}$ ) were purchased from Matheson Trigas. A GC calibration standard for $\mathrm{CH}_{4}, \mathrm{C}_{2} \mathrm{H}_{4}, \mathrm{C}_{2} \mathrm{H}_{6}, \mathrm{C}_{3} \mathrm{H}_{6}$, $\mathrm{C}_{3} \mathrm{H}_{8}$, and 1-butene was purchased from Praxair. $\mathrm{N}_{2}, \mathrm{CO}_{2}$, and zero-grade air were purchased from Airgas. 1-Butanol (99\%) and hydrated nitrate salts of $\mathrm{Cr}, \mathrm{K}, \mathrm{Ca}, \mathrm{Ni}, \mathrm{Fe}, \mathrm{Cu}$, and Ce were purchased from Sigma-Aldrich, as was the oxalate salt of Mo. The $\gamma-\mathrm{Al}_{2} \mathrm{O}_{3}$ catalyst support was from Sasol (Puralox Nwa155). Inert quartz chips (nominally 30-50 mesh) were from Dupré Minerals.

\section{Catalyst synthesis}

Catalysts were synthesized by depositing aqueous solutions of the nitrate salts on a Sasol Puralox Nwa $155 \mathrm{Al}_{2} \mathrm{O}_{3}$ support by incipient wetness. The baseline catalyst was $8.7 \mathrm{wt} \% \mathrm{Cr}_{2} \mathrm{O}_{3}$. The doped catalysts had the same loading of $\mathrm{Cr}_{2} \mathrm{O}_{3}$ plus $1 \mathrm{wt} \%$ of the dopant metal, unless otherwise specified, mixed as the nitrate or oxalate salt in the same solution as the $\mathrm{Cr}$. In the case of $\mathrm{Cu} /$ $\mathrm{CeO}_{2}$, the dopant solution was prepared separately and applied by incipient wetness to the baseline $\mathrm{Cr}_{2} \mathrm{O}_{3} / \mathrm{Al}_{2} \mathrm{O}_{3}$ catalyst. The metal loading for that catalyst was $0.1 \mathrm{wt} \% \mathrm{Cu}$ and $0.9 \mathrm{wt} \% \mathrm{Ce}$.

After depositing the salt solution, the catalysts were dried under vacuum at $40{ }^{\circ} \mathrm{C}$ overnight, then transferred to a ceramic dish and calcined by the following program: ramp to $95{ }^{\circ} \mathrm{C}$ at $25^{\circ} \mathrm{C} \mathrm{min}{ }^{-1}$, hold for $1 \mathrm{~h}$, ramp to $550^{\circ} \mathrm{C}$ at $5^{\circ} \mathrm{C} \mathrm{min}^{-1}$, hold for $10 \mathrm{~h}$. 


\section{Catalyst characterization}

Catalysts were characterized by $\mathrm{N}_{2}$ physisorption to determine surface area, by $\mathrm{NH}_{3}$ temperature programmed desorption (TPD) to quantify acid sites, and by X-ray diffraction (XRD) to evaluate crystal structure. $\mathrm{N}_{2}$ physisorption was carried out on a Quantachrome Quantisorb SI four-station instrument. Prior to analysis, catalysts were outgassed under vacuum at $350{ }^{\circ} \mathrm{C}$ overnight. Eight adsorption points for each catalyst were recorded to establish an isotherm from which the surface area was calculated, using a $30 \mathrm{~s}$ equilibration time for each point.

$\mathrm{NH}_{3}$ pulse chemisorption was carried out on an Altamira Instruments AMI-390 unit. Samples were treated for $2 \mathrm{~h}$ at $450{ }^{\circ} \mathrm{C}$ under $50 \mathrm{~mL} \mathrm{m^{-1 }} \mathrm{Ar}$, then cooled to $120{ }^{\circ} \mathrm{C}$ under flowing He before dosing the sample with $25 \times 5 \mathrm{~mL}$ pulses of $10 \% \mathrm{NH}_{3}$ in $\mathrm{He}$. The average of the post-saturation pulses (typically the last 15-20 pulses) was used as the reference peak area. The adsorbed peak area was calculated as the sum of the difference between the observed peak area and the reference peak area for the unsaturated pulses (typically first 5-10 pulses). The $\mathrm{NH}_{3}$ areas were quantified on a TCD and converted to a quantity of adsorbed molecules assuming ideal gas behaviour of the pulse gas.

XRD was carried out on a Rigaku Ultima IV X-ray diffractometer using $\mathrm{Cu} \mathrm{K-} \alpha$ radiation. The operating voltage and current were $40 \mathrm{kV}$ and $44 \mathrm{~mA}$, respectively. A scan range of 5$80^{\circ} 2 \theta$, a scan speed of $5^{\circ} \mathrm{min}^{-1}$ and a point spacing of $0.05^{\circ} 2 \theta$ were used.

\section{Reactor system}

The reactor system was a fixed-bed downflow stainless steel tubular reactor, $0.5^{\prime \prime}$ ID and $14^{\prime \prime}$ length. Unless otherwise specified, the catalyst bed $(0.6 \mathrm{~g})$ was positioned in the middle of the reactor tube, with 30-50 mesh $\mathrm{SiO}_{2}$ packed upstream and downstream to facilitate mixing and heat transfer. The particles were held in place by a plug of quartz wool on either end of the reactor, and a thermocouple was placed in the middle of the catalyst bed. In the case of the sequential dehydration-dehydrogenation, the thermocouple tip was in the middle of the dehydrogenation catalyst bed. The reactor was brought up to temperature under flowing $\mathrm{N}_{2}$, and typically allowed to equilibrate overnight before starting a reaction. To measure the temperature profile of the reactor, the top of the reactor was fitted with a thermowell that accompanied two K-type thermocouples. A control thermocouple remained in the centre of the tube while the other moved from the bottom of the tube to the top of the tube in $0.5^{\prime \prime}$ increments, and waiting 30-60 s at each point for the temperature to stabilize. When the reactor was heated to the reaction temperature using the control thermocouple in the thermowell, the wall temperature of the furnace was the same as when the control thermocouple was embedded in the catalyst bed, confirming that the temperature profile was the same during measurement and reaction.

During reactor operation, a reaction-purge-regenerationpurge cycle using four mass flow controllers was implemented, with the reactor control software automatically switching between steps. The temperature, time, and flow parameters used for each cycle unless otherwise indicated are shown in Table 1.

For dehydration experiments, a $0.2 \mathrm{~g}$ bed of the same $\gamma-\mathrm{Al}_{2} \mathrm{O}_{3}$ material used to support the $\mathrm{Cr}_{2} \mathrm{O}_{3}$ catalysts was positioned 5 inches $(12.7 \mathrm{~cm})$ above the centre of the reactor tube. At this point, the reactor temperature was $360{ }^{\circ} \mathrm{C}$ when the axial centre of the reactor tube was at $450{ }^{\circ} \mathrm{C}$. The butanol flow rate was 0.02 $\mathrm{mL} \min ^{-1}$, selected to approximate the conditions of the $5.4 \mathrm{~mol} \%$ 1-butene mixture used in the dehydrogenation catalyst screening experiments. The $\mathrm{N}_{2}$ flow rate was $177 \mathrm{sccm}$. For integrated dehydration-dehydrogenation experiments, the configuration for both sets of experiments was combined. A $0.2 \mathrm{~g}$ bed of $\gamma-\mathrm{Al}_{2} \mathrm{O}_{3}$ was positioned 5 inches $(12.7 \mathrm{~cm})$ above the reactor centre and a $0.6 \mathrm{~g}$ bed of $\mathrm{K}-\mathrm{Cr}_{2} \mathrm{O}_{3} / \mathrm{Al}_{2} \mathrm{O}_{3}$ was positioned at the reactor centre, the 1-butanol flow rate was $0.02 \mathrm{~mL} \mathrm{~min}^{-1}$ and the $\mathrm{N}_{2}$ flow rate was $177 \mathrm{sccm}$.

Reactor effluent passed through a condenser and then to local exhaust ventilation, with a slip stream sampled by online GCMS. The system consisted of an Agilent 6890 Plus GC equipped with a TCD, FID, and a 5973 MS, which analysed samples in parallel. The GC column was a $30 \mathrm{~m} \times 0.32 \mathrm{~mm}$ ID GS-GASPRO column, operating in ramped flow mode with the following program: $2.3 \mathrm{~mL} \min ^{-1}$ for $3 \mathrm{~min}$, ramp at $1 \mathrm{~mL}$ $\mathrm{min}^{-2}$ to $2.7 \mathrm{~mL} \mathrm{~min}^{-1}$, hold at $2.7 \mathrm{~mL} \mathrm{~min}^{-1}$. The corresponding oven program was $50{ }^{\circ} \mathrm{C}$ for $3 \mathrm{~min}$, ramp at $15{ }^{\circ} \mathrm{C} \mathrm{min}{ }^{-1}$ to $75{ }^{\circ} \mathrm{C}$, hold for $2 \mathrm{~min}$, ramp at $50{ }^{\circ} \mathrm{C} \mathrm{min}^{-1}$ to $250{ }^{\circ} \mathrm{C}$, hold for $2.83 \mathrm{~min}$. The inlet conditions were $250{ }^{\circ} \mathrm{C}$, initial pressure of $10.64 \mathrm{psi}$, and a split ratio of $20: 1$. The carrier gas for the system was He. Hydrocarbons were quantified on the FID, using $\mathrm{N}_{2}$ (detected on the TCD) as an internal standard, and gas mixes of authentic standards for C1-C4 compounds to develop response factors. For C5 and heavier compounds, FID response factors were calculated based on the method of Scanlon, ${ }^{24}$ though these compounds typically comprised less than $0.5 \%$ carbon yield.

Yields and selectivities are reported on a carbon molar basis. Selectivities are based on the amount of butene fed rather than as a fraction of products detected.

Table 1 Reactor parameters for butene dehydrogenation

\begin{tabular}{lllll}
\hline Parameter & Reaction & Reaction purge & Regeneration & Regeneration purge \\
\hline Temperature & $450{ }^{\circ} \mathrm{C}$ & $450{ }^{\circ} \mathrm{C}$ & $450{ }^{\circ} \mathrm{C}$ & $450{ }^{\circ} \mathrm{C}$ \\
Duration & $72 \mathrm{~min}$ & $6 \mathrm{~min}$ & $74 \mathrm{~min}$ & $6 \mathrm{~min}$ \\
Gas feed & $100 \mathrm{sccm} \mathrm{N}$ or CO $_{2}+$ & $200 \mathrm{sccm} \mathrm{N}{\text { or } \mathrm{CO}_{2}}^{2}$ & $100 \mathrm{sccm} \mathrm{Ar}+100$ sccm zero air & $200 \mathrm{sccm} \mathrm{Ar}$
\end{tabular}




\section{Results}

\section{Butanol dehydration}

We initially explored butanol dehydration under conditions similar to those reported by Pines and Haag. ${ }^{8}$ Using a temperature of $360{ }^{\circ} \mathrm{C}$ and WHSV of $4.86 \mathrm{~h}^{-1}\left(0.2 \mathrm{~g} \gamma-\mathrm{Al}_{2} \mathrm{O}_{3}\right.$ catalyst bed and $0.02 \mathrm{~mL} \mathrm{~min}^{-1}$ butanol flow rate), we were able to obtain $>95 \%$ carbon balance and $91 \%$ yield to linear butenes over $\sim 100$ min time-on-stream, as shown in Fig. 1 . These were the conditions we employed in the integrated dehydration-dehydrogenation experiments.

We also explored butanol reactivity at $450{ }^{\circ} \mathrm{C}$, consistent with the butene dehydrogenation conditions reported below. Butanol conversion in $\mathrm{S} \mathrm{SiO}_{2}$-packed tube (without catalyst) was $100 \%$, but selectivity to butenes was low, and a significant amount of black solid was deposited in the reactor. Because conversion of butenes under these conditions was negligible (see below), the high conversion of butanol suggests thermal reactions through non-butene routes predominated, such as cracking, coke formation, dehydrogenation to butyraldehyde, and decarbonylation of butyraldehyde to produce propene and CO.

We attempted to mitigate these nonselective reactions by inserting a $\gamma-\mathrm{Al}_{2} \mathrm{O}_{3}$ catalyst bed upstream of the axial tube centre to convert the butanol to butenes at $450{ }^{\circ} \mathrm{C}$. However, when the $\gamma-\mathrm{Al}_{2} \mathrm{O}_{3}$ bed was positioned within the isothermal zone of the reactor, a significant amount of isobutene was produced through skeletal isomerization. Thus, we measured the temperature profile within the reactor tube and placed the $\gamma-\mathrm{Al}_{2} \mathrm{O}_{3}$ bed 5 inches $(12.7 \mathrm{~cm})$ above the axial centre of the reactor, at which point the temperature was $360{ }^{\circ} \mathrm{C}$ (Fig. S1 $\dagger$ ), consistent with Pine and Haags. ${ }^{8}$ This was the location of the $\gamma-\mathrm{Al}_{2} \mathrm{O}_{3}$ bed in the integrated experiments.

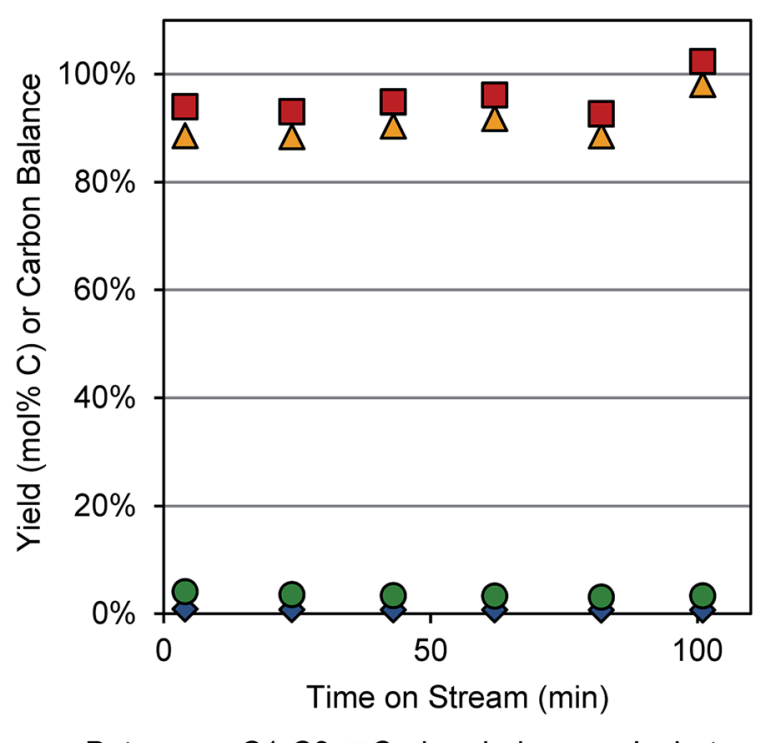

$\Delta$ Butenes $\diamond$ C1-C3 $\square$ Carbon balance Olsobutene

Fig. 1 Dehydration of 1-butanol to 1- and 2-butenes over a $\gamma-\mathrm{Al}_{2} \mathrm{O}_{3}$ catalyst. Reaction conditions: $0.02 \mathrm{~mL} \mathrm{~min}^{-1}$ butanol, $177 \mathrm{sccm} \mathrm{N} \mathrm{N}_{2}$, $0.2 \mathrm{~g}$ catalyst, $350-400^{\circ} \mathrm{C}$.

\section{Screening of butene dehydrogenation reaction conditions}

To establish reaction conditions for butene dehydrogenation that would maximize butadiene selectivity, maximize singlepass yield, and minimize cracking reactions, we explored different temperatures and space velocities with the baseline $\mathrm{Cr}_{2} \mathrm{O}_{3} / \mathrm{Al}_{2} \mathrm{O}_{3}$ catalyst. The results of these experiments are shown in Fig. 2. Selectivity and yield are optimal at $450{ }^{\circ} \mathrm{C}$ and $0.76 \mathrm{~h}^{-1}$ weight hourly space velocity (WHSV), while both lower and higher temperatures show lower selectivity. At $400{ }^{\circ} \mathrm{C}$, the lower selectivity is likely due to coke formation as no other compounds were observed in the effluent stream, while at $500{ }^{\circ} \mathrm{C}$, both coke formation and cracking reactions play a role, as $\mathrm{C} 1-\mathrm{C} 3$ hydrocarbons were detectable, along with small amounts of C5 hydrocarbons, benzene, and toluene. These results show that high butadiene yields and selectivities can be obtained at temperatures significantly lower than those typically used for direct butene dehydrogenation. Notably, following the analysis of Tyuryaev, ${ }^{9}$ the 1 butene dehydrogenation equilibrium at a 1-butene partial pressure of $0.027 \mathrm{~atm}$ and temperatures of $400{ }^{\circ} \mathrm{C}$ and $450{ }^{\circ} \mathrm{C}$ would give $18-22 \%$ and $35-39 \%$ yields to butadiene, respectively. At $500{ }^{\circ} \mathrm{C}, 57-60 \%$ butadiene yields would be predicted. Thus, it appears that the butadiene yield at 400$450{ }^{\circ} \mathrm{C}$ is limited by equilibrium, while at $500{ }^{\circ} \mathrm{C}$, it is limited by side reactions.

Thus, we established $450{ }^{\circ} \mathrm{C}$ and a space velocity of $0.76 \mathrm{~h}^{-1}$ WHSV as the operating conditions for our remaining experiments. Notably, the butadiene selectivity and yields are comparable to common industrial catalysts reported for direct dehydrogenation. ${ }^{9}$ Under these same conditions, a control reaction (reactor tube packed with only $\mathrm{SiO}_{2}$ ) showed $<5 \%$ conversion of 1-butene (Fig. S2 $\dagger$ ).

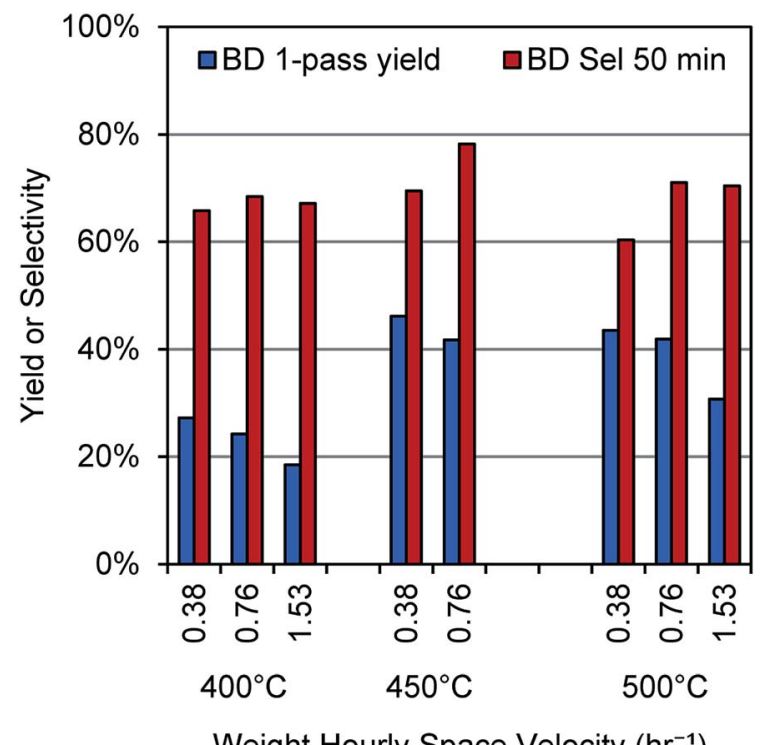

Fig. 2 Yields and selectivity for butene dehydrogenation over a $\mathrm{Cr}_{2} \mathrm{O}_{3} /$ $\mathrm{Al}_{2} \mathrm{O}_{3}$ catalyst. Results calculated at 50 min time on stream with a $2.7 \mathrm{~mol} \%$ concentration of 1-butene in $\mathrm{N}_{2}$. 


\section{Effect of catalyst dopant and reaction atmosphere}

In the interest of improving the butene dehydrogenation portion of the reactor by subsequently reacting produced $\mathrm{H}_{2}$, we tested a number of $1 \mathrm{wt} \%$ doped catalysts in $\mathrm{N}_{2}$ and $\mathrm{CO}_{2}$ rich atmospheres. The feed composition of these atmospheres were $97.3 \% \mathrm{~N}_{2}$ and $47.3 \% \mathrm{~N}_{2} / 50.0 \% \mathrm{CO}_{2}$, respectively, with $2.7 \%$ 1-butene in both cases. For two reaction cycles in $\mathrm{N}_{2}$, two in $\mathrm{CO}_{2}$, and one in $\mathrm{N}_{2}$, the doped catalysts were generally comparable to the undoped $\mathrm{Cr}_{2} \mathrm{O}_{3} / \mathrm{Al}_{2} \mathrm{O}_{3}$ catalyst, except that the $\mathrm{K}$-doped catalyst was slightly better in $\mathrm{N}_{2}$, the $\mathrm{Ni}$-doped catalyst was slightly better in $\mathrm{CO}_{2}$, and the $\mathrm{K}$ - and Ca-doped catalysts were slightly worse in $\mathrm{CO}_{2}$. These results are shown in Fig. 3. We also tested Ni- and Mo-doped catalysts at $0.25 \mathrm{wt} \%$ and $5 \mathrm{wt} \%$ metal dopant loadings, but the results were similar to the 1 wt $\%$ loading (Fig. S3†). The corresponding selectivities are also quite high, with several catalysts giving greater than $80 \%$ selectivity at 30 min timeon-stream (TOS, Fig. S4 $\dagger$ ).

The $\mathrm{CO}_{2}$-enriched atmosphere did not lead to higher butadiene yields as hypothesized, despite the more favourable equilibria for $\mathrm{H}_{2}$ conversion. (For example, correlations for the water-gas shift equilibrium ${ }^{25}$ at 1 atm and $450{ }^{\circ} \mathrm{C}$ predict greater than $98 \%$ conversion of produced $\mathrm{H}_{2}$ in a $50 \% \mathrm{CO}_{2}$ atmosphere). In these reactions, there was not a significantly higher amount of $\mathrm{CH}_{4}$ produced (as would be expected from methanation of $\mathrm{C}$ or $\mathrm{CO}_{2}$ ), nor was any condensate collected from the reactor knockout pot, (as may be expected from $\mathrm{H}_{2} \mathrm{O}$ production via enhanced RWGS activity). Thus, it seems that the catalysts synthesized here are either not capable of activating $\mathrm{CO}_{2}$ or not capable of catalysing the desired reactions at $450{ }^{\circ} \mathrm{C}$. Further catalyst development will be the focus of future work.

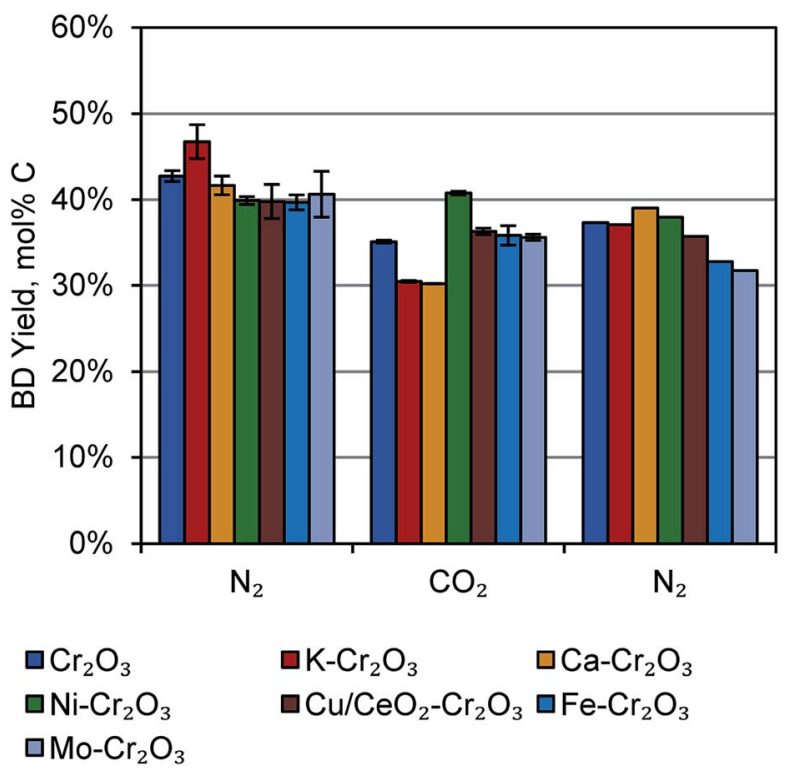

Fig. 3 Conversion and selectivity in 1-butene dehydrogenation over 1 wt\% metal-doped $\mathrm{Cr}_{2} \mathrm{O}_{3}$ catalysts, interpolated to 30 min time-onstream. Left-most set: reaction cycles 1-2 in $\mathrm{N}_{2}$. Centre set: reaction cycles 3-4 in $\mathrm{N}_{2} / \mathrm{CO}_{2}$. Right-most set: reaction cycle 5 in $\mathrm{N}_{2}$.

\section{Integration of butanol dehydration and butene} dehydrogenation

With these results, we were motivated to integrate the dehydration and dehydrogenation reactions in a single reactor tube. The reactor configuration consisted of a $0.6 \mathrm{~g}$ bed of the $1 \mathrm{wt} \% \mathrm{~K}$-doped $\mathrm{Cr}_{2} \mathrm{O}_{3} / \mathrm{Al}_{2} \mathrm{O}_{3}$ catalyst at the centre of the reactor tube (at $450{ }^{\circ} \mathrm{C}$ ), a $0.2 \mathrm{~g}$ bed of $\gamma-\mathrm{Al}_{2} \mathrm{O}_{3}$ positioned 5 inches $(12.7$ $\mathrm{cm}$ ) above the centre of the tube (at $360{ }^{\circ} \mathrm{C}$ ), a butanol flow of $0.02 \mathrm{~mL} \min ^{-1}$, and an $\mathrm{N}_{2}$ flow of $177 \mathrm{sccm}$. Under these conditions, we were able to obtain $\sim 13 \%$ single-pass yields over $10 \mathrm{~h}$ TOS, as shown in Fig. 4. The gap between 200 and 300 min TOS represents a regeneration step, though the catalyst performance appeared to be decreasing only slightly with TOS. In dehydrogenation of 1-butene, catalyst performance decreased more rapidly (though maintaining higher overall yields). Thus, the integrated process with butanol feed appears to be more stable than just the dehydrogenation. The reason for this difference is not clear at this point, but it may be that the oxygen in the butanol feed is able to mitigate coke formation. Because this oxygen would likely only see the dehydrogenation catalyst as $\mathrm{H}_{2} \mathrm{O}$, it is likely that any cokemitigating function is due to $\mathrm{H}_{2} \mathrm{O}$ rather than 1-butanol specifically.

The yield of butadiene in the integrated process is lower than expected from the previous runs, which produced $>40 \%$ yields of butadiene from 1-butene at $30 \mathrm{~min}$ TOS. We tentatively ascribe the lower yields to the water sensitivity of $\mathrm{Cr}_{2} \mathrm{O}_{3} / \mathrm{Al}_{2} \mathrm{O}_{3}$ catalysts, ${ }^{9}$ as $\mathrm{H}_{2} \mathrm{O}$ is produced in the dehydration step. Indeed, dehydrogenation activity was much lower when co-feeding 0.02 $\mathrm{mL} \min ^{-1}$ of $\mathrm{H}_{2} \mathrm{O}$ with the 1-butene/ $\mathrm{N}_{2}$ mixture over these catalysts (Fig. $\mathrm{S} 5 \dagger$ )

Notably, while the single-pass butadiene yield is only $13 \%$, the average selectivity to linear C4 compounds is $>95 \%$ (Fig. S6†). The remaining mass is likely due to coke formation,

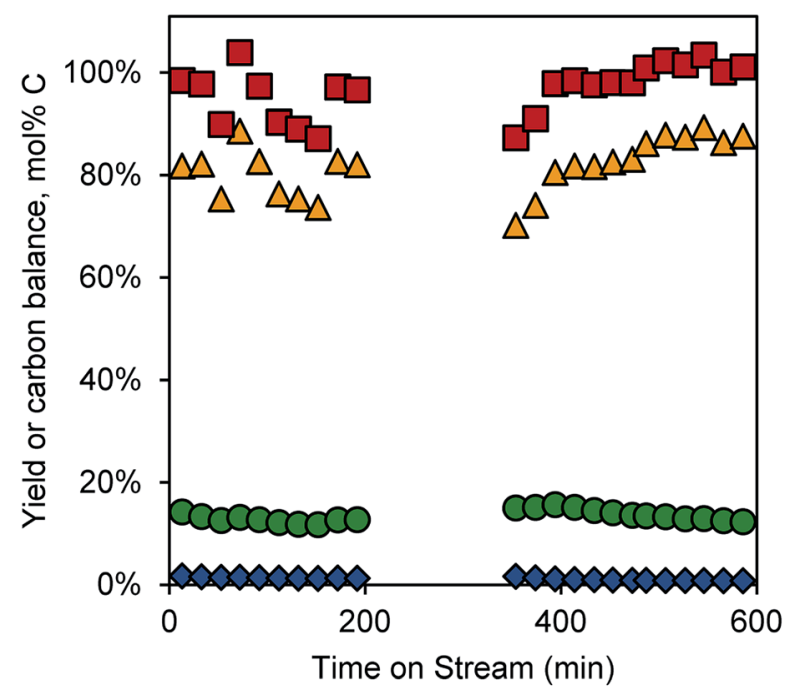

$\Delta$ Butenes $\diamond$ C1-C3 $\square$ Carbon balance oButadiene

Fig. 4 Integrated butanol dehydration and butene dehydrogenation. 
Table 2 Surface area and acidity of selected catalysts synthesized in this work

\begin{tabular}{lll}
\hline Catalyst & BET surface area $\left(\mathrm{m}^{2} \mathrm{~g}^{-1}\right)$ & $\mathrm{NH}_{3}$ uptake $\left(\mu \mathrm{mol} \mathrm{g}{ }^{-1}\right)$ \\
\hline $\mathrm{Al}_{2} \mathrm{O}_{3}$ & 153 & 242 \\
$\mathrm{Cr}_{2} \mathrm{O}_{3}$ & 139 & 424 \\
$1 \mathrm{~K}^{-} \mathrm{Cr}_{2} \mathrm{O}_{3}$ & 137 & 334
\end{tabular}

as some $\mathrm{CO}_{2}$ could be detected during the regeneration cycle. Thus, with a recycle reactor, the overall achievable yield of butadiene from butanol would be nearly quantitative using the present conditions.

\section{Catalyst characterization}

We characterized the fresh catalysts for surface area, acidity, and phase composition. Catalyst surface area and acidity are shown in Table 2, while phase composition is shown in Fig. S7. $\dagger$

The $\gamma-\mathrm{Al}_{2} \mathrm{O}_{3}$ support had a surface area of $153 \mathrm{~m}^{2} \mathrm{~g}^{-1}$, which was reduced slightly after deposition of $\mathrm{Cr}_{2} \mathrm{O}_{3}$ and calcining to decompose the precursor salt. The presence of $\mathrm{K}$ in the $\mathrm{Cr}$ precursor solution does not significantly decrease the surface area further. Because high-valent $\mathrm{Cr}$ catalysts are known to decompose $\mathrm{NH}_{3}$ at temperatures above about $500{ }^{\circ} \mathrm{C},{ }^{26}$ we quantified acid sites by $\mathrm{NH}_{3}$ pulse chemisorption instead of $\mathrm{NH}_{3}$ TPD. The $\mathrm{NH}_{3}$ uptake on the $\gamma-\mathrm{Al}_{2} \mathrm{O}_{3}$ support suggests an acid site content of $242 \mu \mathrm{mol}$ sites/g. Addition of $\mathrm{Cr}_{2} \mathrm{O}_{3}$ increases the acid site content to $424 \mu \mathrm{mol} \mathrm{sites} / \mathrm{g}$, while the presence of $\mathrm{K}$ in the $\mathrm{Cr}$ precursor solution mitigates the increase in acid sites to $334 \mu \mathrm{mol}$ sites/g. Doping $\mathrm{Cr}$ oxide catalysts with $\mathrm{K}$ has been hypothesized to poison acid sites, ${ }^{9}$ though recent work has suggested that $\mathrm{K}$ also changes the surface morphology of the supported Cr oxide phase. ${ }^{27}$ Any structural changes were not apparent by XRD, as only peaks for the $\gamma-\mathrm{Al}_{2} \mathrm{O}_{3}$ support could be detected in the prepared catalysts (Fig. S7†).

\section{Conclusions}

We have integrated 1-butanol dehydration with butene dehydrogenation to produce 1,3-butadiene in a one-tube, two-stage process. Dehydration of 1-butanol gives linear butenes in $>90 \%$ yield over a $\gamma-\mathrm{Al}_{2} \mathrm{O}_{3}$ catalyst at $350-410{ }^{\circ} \mathrm{C}$. Dehydrogenation of 1-butene gives single-pass butadiene yields greater than $40 \%$ at $450{ }^{\circ} \mathrm{C}$ for a 2.7 vol\% butene feed in $\mathrm{N}_{2}$, with selectivity greater than $80 \%$ at $30 \mathrm{~min}$ TOS. The integrated process demonstrated here gives an average single-pass butadiene yield of $13 \%$, with overall C4 selectivity greater than $95 \%$. With a recycle reactor configuration, overall yields of 1-butanol to butadiene would be much higher. Additionally, these results are obtained at temperatures significantly lower than those traditionally used for direct butene dehydrogenation, representing a potential route for decreasing process severity in butadiene production. Thus, the process developed here is an important step in the production of renewable butadiene.

\section{Conflicts of interest}

There are no conflicts to declare.

\section{Acknowledgements}

This work was authored by the National Renewable Energy Laboratory (NREL), operated by Alliance for Sustainable Energy, LLC, for the U.S. Department of Energy (DOE) under Contract No. DE-AC36-08GO28308. This work was supported by the Laboratory Directed Research and Development (LDRD) Program at NREL. The views expressed in the article do not necessarily represent the views of the DOE or the U.S. Government. The U.S. Government retains and the publisher, by accepting the article for publication, acknowledges that the U.S. Government retains a nonexclusive, paid-up, irrevocable, worldwide license to publish or reproduce the published form of this work, or allow others to do so, for U.S. Government purposes.

\section{Notes and references}

1 E. V. Makshina, M. Dusselier, W. Janssens, J. Degreve, P. A. Jacobs and B. F. Sels, Chem. Soc. Rev., 2014, 43, 79177953.

2 M. J. Biddy, C. Scarlata and C. Kinchin, Chemicals from Biomass: A Market Assessment of Bioproducts with Near-Term Potential. Technical Report NREL/TP-5100-65509, National Renewable Energy Laboratory, 2016.

3 Z. Xi and W.-X. Zhang, Synlett, 2008, 2008, 2557-2570.

4 M. D. Jones, Chem. Cent. J., 2014, 8, 53.

5 P. C. A. Bruijnincx and B. M. Weckhuysen, Angew. Chem., Int. Ed., 2013, 52, 11980-11987.

6 Nexant, Final Report: Renewable Chemicals \& Materials Opportunity Assessment, Major Job Creation and Agricultural Sector Engine, Prepared for US Department of Agriculture, 2014.

7 J. S. Kruger, R. Chakrabarti, R. J. Hermann and L. D. Schmidt, Appl. Catal., A, 2012, 411, 87-94.

8 H. Pines and W. O. Haag, J. Am. Chem. Soc., 1961, 83, 28472852.

9 I. Y. Tyuryaev, Russ. Chem. Rev., 1966, 35, 59.

$10 \mathrm{~J}$. Grub and E. Löser, in Ullmann's Encyclopedia of Industrial Chemistry, Wiley-VCH Verlag GmbH \& Co. KGaA, 2000, DOI: 10.1002/14356007.a04_431.

11 R. Julius, F. Robert, A. Claudia and D. Olaf, AIChE J., 2017, 63, 43-50.

12 H. Lee, J. C. Jung, H. Kim, Y.-M. Chung, T. J. Kim, S. J. Lee, S.-H. Oh, Y. S. Kim and I. K. Song, Catal. Commun., 2008, 9, 1137-1142.

13 S. Chen, A. Sun, Z. Qin and J. Wang, Catal. Commun., 2003, 4, 441-447.

14 L. Zhang, Z. Wu, N. C. Nelson, A. D. Sadow, I. I. Slowing and S. H. Overbury, ACS Catal., 2015, 5, 6426-6435.

15 Y. Yue, L. Zhang, J. Chen, D. K. Hensley, S. Dai and S. H. Overbury, RSC Adv., 2016, 6, 32989-32993.

16 W. Yan, Q. Y. Kouk, J. Luo, Y. Liu and A. Borgna, Catal. Commun., 2014, 46, 208-212. 
17 W. Yan, J. Luo, Q.-Y. Kouk, J. E. Zheng, Z. Zhong, Y. Liu and A. Borgna, Appl. Catal., A, 2015, 508, 61-67.

18 W. Yan, Q.-Y. Kouk, S. X. Tan, J. Luo and Y. Liu, J. CO2 Util., 2016, 15, 154-159.

19 Y. Gao, B. Wang, B. Yan, J. Li, F. Alam, Z. Xiao and T. Jiang, React. Kinet., Mech. Catal., 2017, 122, 451-462.

20 A. A. Lizzio and L. R. Radovic, Ind. Eng. Chem. Res., 1991, 30, 1735-1744.

21 T. A. Le, M. S. Kim, S. H. Lee, T. W. Kim and E. D. Park, Catal. Today, 2017, 293, 89-96.

22 S. Rönsch, J. Schneider, S. Matthischke, M. Schlüter, M. Götz, J. Lefebvre, P. Prabhakaran and S. Bajohr, Fuel, 2016, 166, 276-296.
23 X. Qi and M. Flytzani-Stephanopoulos, Ind. Eng. Chem. Res., 2004, 43, 3055-3062.

24 J. T. Scanlon and D. E. Willis, J. Chromatogr. Sci., 1985, 23, 333-340.

25 C. Callaghan, PhD thesis, Worcester Polytechnic Institute, 2006.

26 L. Li, Z. H. Zhu, S. B. Wang, X. D. Yao and Z. F. Yan, J. Mol. Catal. A: Chem., 2009, 304, 71-76.

27 V. S. Sullivan, S. D. Jackson and P. C. Stair, J. Phys. Chem. B, 2005, 109, 352-356. 